\title{
Skill Development of Students through Hands-on Workshop
}

\author{
Manisha R. Admane ${ }^{1}$, Parag J. Mondhe ${ }^{2}$ \\ ${ }^{1}$ Professor, Department of Electronics and Telecommunication Engineering, \\ K. K. Wagh Institute of Engineering Education and Research, Nashik, Maharashtra, India. \\ ${ }^{2}$ Assistant Professor, Department of Electronics and Telecommunication Engineering, \\ K. K. Wagh Institute of Engineering Education and Research, Nashik, Maharashtra, India. \\ ${ }^{1}$ mpsatone@kkwagh.edu.in \\ ${ }^{2}$ mondheparag@gmail.com
}

\begin{abstract}
Now a days, lot of focus is given to innovative teaching and learning methodologies. The aim of this paper is to engage and motivate the students for lifelong learning. Moreover, it is also necessary to enhance the skills of the students. Keeping this objective in mind, hands-on workshop was organized for the third year engineering students of Electronics branch of the institute. The workshop was aimed to enhance hands-on skills among the students. The workshop also focused on boosting the confidence level of the weak students in the class. Equal number of bright and weak students were selected for this workshop. The students were identified by considering few parameters such as performance in pre-requisite theory course, performance in pre-requisite laboratory course, performance in pre-requisite knowledge test, and feedback from the mentor. It is observed that the weak students outperformed bright students in hands-on skills assignment. Weak students showed enthusiasm while performing hands-on than solving theoretical assignment. Whereas few bright students couldn't speed up with weak students in hands-on but they were interested in solving theoretical assignments. It was also observed that students gave overwhelming response in solving open ended design assignment and its implementation. This assignment has attained the highest level of Bloom's taxonomy. This study concludes that performance of the students depends on their interest. In future, students can be categorized in three levels as bright, average and weak and suitable activities can be planned for their skills development.
\end{abstract}

\section{Dr. Manisha R. Admane}

Professor, Department of Electronics and

Telecommunication, K. K. Wagh Institute of Engineering Education and Research, Nashik, Maharashtra, India. mpsatone@kkwagh.edu.in

Keywords: Hands-on workshop, skills development, weak and bright students, open ended design and implementation assignment

\section{Introduction}

Famous writer Cassandra Clare quoted "Everyone has the potential to be extraordinary". Each individual is unique with different Intelligence Quotient (IQ) levels and every human has their own way of doing things. Not all humans have unique strengths. Some might be good at hands-on and some at theory. Some students have the capability of grabbing fast and remember for long whereas others have contradictory capacity. At schools or colleges, both types of students are observed. It is necessary that teachers should understand strength and weakness of bright and weak students and they should take care of each and every student as per their specific needs. Weak students or slow learners require extra attention. Punishing a weak student won't provide the necessary solution.

Aristotle the famous philosopher quoted that "For the things we have to learn before we can do them, we learn by doing them" and this is true in areas of study such as technology, engineering which require activities. Experiential learning usually known as hands-on learning is supposed to be the most effective method of learning things that is learning by doing. Hands-on training is used for teaching students how to perform specific tasks. It allows students to apply their knowledge to real-world scenarios. Unlike traditional classroom teaching, where learners listen to lectures, and they might view photos, illustrations and videos, hands-on learners are actively involved. For many people, it is a better way to learn because they can easily remember something they have done, as opposed to something they have read or they have heard.

Hands-on learning is the process of teaching students to observe things around them and experiment on it. In handson, environment is stress free, students can experiment repeatedly and they can learn from their mistakes. This trial and error approach of problem solving helps the students to better understand the concepts. Students also understand that the mistakes and failures are part of the learning process. Keeping this thought in mind, hands-on workshop was conducted to explore the skill development ability among the students and to check the strength of the weak students. The objectives of the workshop were:

- To bridge the curriculum gap present in the syllabus of "Embedded Processor" course as students are not exposed to the ready to use microcontroller's structure through the curriculum. 
- To provide an opportunity for students to get aware of Arduino and thereby developing a stepping stone towards the development of an embedded system.

- To boost the confidence level of weak students.

The institute follows the syllabus drafted by the University as it is affiliated to it. The curriculum gap observed in the syllabus of the "Embedded Processor" course, is bridged by organizing this "Hands-on Workshop on Arduino".

The paper is organized as follows: Section 2 reviews the literature, section 3 covers the methodology, which is divided into 2 subsections. The subsection A elaborates the process of identification of weak and bright students while subsection B provides details of the workshop. The section 4 contains results of the workshop and discussion on its analysis.

\section{Literature Review}

To succeed in life, students should be able to apply what they have learned from the variety of scenarios. Handson learning teach them to implement the concepts they have learned. Information is easier to remember when students are actively engaged in the learning process. Using hands-on technique, students grasp concepts much quicker than if they read or listen. Today's engineering employers are highly appreciating a student with technical skills. The main concern of faculty that teaches undergraduate engineering courses is how well the students are trained with the practical skills required by industry. In the article "Hands on Learning for Freshman Engineering Students", Julie Arnold et al. [1] had mention that hands-on learning can increase the confidence level of engineers in the workplace. In the article "Hands-on experiences in engineering classes: The need, the implementation and the results", [2] Daniela Pusca and Derek Northwood focused on the need for the hands-on experiences in engineering instructional laboratories. They used modeling method in the conceptual design information process. They concluded that hands-on activities can cultivate the development of knowledge and skills in both the cognitive and affective domains like design, creativity, communication, models and team work in the students. They also state the importance of both virtual and physical materials for hands-on activities, which must be designed to produce long-lasting skills. They focused on minds-on which promotes deeper thinking, and leads to deeper understanding.

In the article "Hands-on Activities and their Influence on Students' Interest", Nina Holstermann and Dietmar Grube [3] investigates the effect of hands-on activities on students' interest. They compared the interest of students having experience in specific hands-on activities with the students without experience. They also examined the relationship between the quality of the hands-on experience and interest in the respective activity. Their findings indicated that the performance of hands-on activities can affect students' interest differently. They conducted seven hands-on activities. Out of seven, in six activities they were identified a positive effect of hands-on experience on interest. In one activity, practical work influenced students' interest negatively. In most hands-on activities, no effect of experience was found on interest. In their activities the quality of hands-on experiences showed positive correlations with interest in the respective hands-on activities.

Dr. U M Daivagna, S B Yapalaparvi, D N Inaamadar, N K Honnagoudar in their paper [4], "Towards improving the Performance of the Weak Students through Identification and Effective Implementation of Tasks by the Quality Circle", used Pareto analysis to identify weak students. They formed a quality circle to improve the performance of weak students. They used strategies like guiding, monitoring assignment submissions, counselling, evaluation etc. to improve the performance of weak students. They also conducted micro classes and motivated students through quotes by great people. They achieved improvement of students' performance in academics as well as in their career.

Wan Maziah Wan Ab Razak, Sharifah Alia Syed Baharom, Zalinawati Abdullah, Haslenna Hamdan, Nurul Ulfa Abd Aziz, and Ahmad Ismail Mohd Anuar in their paper [5] "Academic Performance of University Students: A Case in a Higher Learning Institution" did research to identify the relationships between factors such as teaching and learning process, infrastructure of University, family and peers influence, and students' financial status with academic performance of degree students in a higher learning institution. From the research they concluded that teachers need to use innovative ideas of teaching process, the institution need to take care of the student's requirements of learning process, and more attentions needs to be given to weak students. Study was conducted in sample engineering institutions in Gujarat, Karnataka, Maharashtra, and Uttar Pradesh by World Bank during 2009-10 [6]. They concluded that, every institution is working in a different situation handling diverse students. Hence, there cannot be a single solution to a problem of weak students' performance.

In the paper "A Comparative Study for Determining the Impact of Emulation based, Hands-on and Feedback Mechanisms on Students' Learning in Engineering Technology and Computer Networking Programs" Dr. M. T. Taher, Dr. Usman Ghani and Dr. Ahmed S. Khan [7] discussed about their findings and they concluded that simulation itself is not very effective in advancing students' learning. Simulation is effective when it is followed by hands-on activity and feedback mechanisms.

Table 1. Identification of Weak and Bright Students 


\begin{tabular}{|c|c|c|c|c|c|c|}
\hline Name & $\begin{array}{l}\text { Performance in } \\
\text { Pre-requisite } \\
\text { Theory } \\
\text { Course: Digital } \\
\text { Electronics }\end{array}$ & $\begin{array}{l}\text { Performance in } \\
\text { Pre-requisite } \\
\text { Laboratory } \\
\text { Course: Digital } \\
\text { Electronics } \\
\text { Lab Practice }\end{array}$ & $\begin{array}{c}\text { Pre-requisite } \\
\text { Knowledge } \\
\text { Test }\end{array}$ & $\begin{array}{c}\text { Feedback from } \\
\text { Mentor }\end{array}$ & Total & Identification \\
\hline Student 1 & 7 & 8 & 8 & 8 & 31 & Bright \\
\hline Student 2 & 8 & 10 & 7 & 8 & 33 & Bright \\
\hline Student 3 & 5 & 5 & 6 & 6 & 22 & Weak \\
\hline . & . & . & . & . & . & . \\
\hline . & . & . & . & . & . & . \\
\hline Student 29 & 4 & 5 & 6 & 7 & 22 & Weak \\
\hline Student 30 & 3 & 4 & 5 & 5 & 17 & Weak \\
\hline
\end{tabular}

They recommended the use of simulation based, hands-on, and feedback based teaching methodologies for improving student learning. Durik and Harackiewicz, in their paper "Different strokes for different folks: How individual interest moderates the effects of situational factors on task interest" [8] described that, all learners will not have same level of interest in same subject. According to their study, students' pre-existing interest and level of competency for a given topic is very important. They have given example that visually stimulating attractive features such as adding color, using different fonts, and bright pictures to math jobs improved situational interest for students who had low interest in math, but it had a negative effect for students those had more developed interest in math. This concludes that, some activities may gain attention of low-interest students, however the highly interested students can get distracted.

\section{Methodology}

The "Hands-on Workshop on Arduino" had blend of hands-on training with lecture-based learning. It was designed to allow students to experience a project based workflow. This workshop was organized for students undergoing "Embedded Processor" course of third year electronics engineering programme of the institute in academic year 2018 - 2019. The workshop was organized for two days and sessions were followed by theoretical and hands-on laboratory assignments. In the last session, open ended design assignment was given to the students for implementation to challenge higher order thinking. To maintain confidentiality, actual names of students are not disclosed in this paper.

\section{A. Identification of Weak and Bright Students}

The workshop was limited to 30 students for better personal guidance. Equal number of weak and bright students were selected for this workshop. For bright students, ratio of female to male students was 10:5 while for weak it was 9:6, which reflects the trend of girl students opting for engineering as a career. Students were categorises as bright or weak based on predefined criteria. The criteria constitutes 4 parameters which were as follows: performance in prerequisite theory course, performance in pre-requisite laboratory course, performance in pre-requisite knowledge test, and feedback from the mentor.
The pre-requisite theory course for the course under study was "Digital Electronics", which students have completed in their second year. Hence students' performance in University written examination of that course is selected as criterion to assess their understanding of basic concepts. The pre-requisite laboratory course for the course under study was "Digital Electronics Lab Practice". From the result of University practical examination of this pre-requisite course, competency of students' hands-on skills can be judged. To evaluate students' interest in the topic of workshop, prerequisite knowledge test was conducted. The institute has a vibrant mentor scheme, in which one faculty is assigned to each student who provides counselling for the students regularly to solve their academic and personal problems. The mentor tracks the academic progress of respective student therefore her feedback is valuable in this process.

For each criterion, 10 marks were allotted. If total score of the student, on these four criteria was over $60 \%$ (24 marks and above out of 40), then that student is identified as a bright student otherwise as a weak student. The $60 \%$ criterion is chosen to maintain consistency with the affiliated University, who considers $60 \%$ as a benchmark to award first class to engineering graduates. This process of identifying student as a bright or weak was confidential and students were neither informed about this identification nor about this experimental research. The Table 1 shows the few entries of academic year 2018-19 class of third year electronics engineering students from the institute.

\section{B. Workshop Details}

On each day of workshop, 3 sessions were conducted so there were 6 sessions conducted by expert faculty during the entire workshop. The Table 2 provides the details of the workshop schedule.

Table 2. Workshop Schedule

\begin{tabular}{|c|c|c|c|}
\hline \multirow{2}{*}{ Day 1 } & Session 1 & Session 2 & Session 3 \\
\cline { 2 - 4 } & Lecture & $\begin{array}{c}\text { Lecture + } \\
\text { Hands-on }\end{array}$ & $\begin{array}{c}\text { Lecture }+ \\
\text { Hands-on }\end{array}$ \\
\hline \multirow{3}{*}{$\begin{array}{c}\text { Types of } \\
\text { assessment }\end{array}$} & $\begin{array}{c}\text { Theoretical } \\
\text { assignment }\end{array}$ & $\begin{array}{c}\text { Theoretical }+ \\
\text { hands-on } \\
\text { laboratory } \\
\text { assignment }\end{array}$ & $\begin{array}{c}\text { Theoretical }+ \\
\text { hands-on } \\
\text { laboratory } \\
\text { assignment }\end{array}$ \\
\hline \multirow{3}{*}{ Day 2 } & Session 4 & Session 5 & Session 6 \\
\cline { 2 - 4 } & Lecture + & Lecture + & $\begin{array}{c}\text { Open Ended } \\
\text { Problem } \\
\text { Hands-on }\end{array}$ \\
\hline
\end{tabular}




\begin{tabular}{|c|c|c|c|}
\hline $\begin{array}{c}\text { Types of } \\
\text { assessment }\end{array}$ & $\begin{array}{c}\text { Theoretical }+ \\
\text { hands-on } \\
\text { laboratory } \\
\text { assignment }\end{array}$ & $\begin{array}{c}\text { Theoretical }+ \\
\text { hands-on } \\
\text { laboratory } \\
\text { assignment }\end{array}$ & $\begin{array}{c}\text { Design }+ \\
\text { implementation } \\
\text { assignment }\end{array}$ \\
\hline
\end{tabular}

Table 3. Performance of Students in Theoretical Assignment

\begin{tabular}{|c|c|c|c|c|c|c|c|c|}
\hline Name & $\begin{array}{c}\text { Identifica } \\
\text { tion }\end{array}$ & Session 1 & Session 2 & Session 3 & Session 4 & Session 5 & Total & Remark \\
\hline Student 1 & Bright & 7 & 7 & 8 & 8 & 6 & 36 & $\begin{array}{l}\text { Good Conceptual } \\
\text { Knowledge }\end{array}$ \\
\hline Student 2 & Bright & 8 & 9 & 8 & 8 & 6 & 39 & $\begin{array}{l}\text { Good Conceptual } \\
\text { Knowledge }\end{array}$ \\
\hline Student 3 & Weak & 4 & 5 & 4 & 3 & 3 & 19 & $\begin{array}{l}\text { Scope for Conceptual } \\
\text { Knowledge Improvement }\end{array}$ \\
\hline . & - & . & . & . & . & . & $\cdot$ & . \\
\hline • & . & . & . & . & . & . & . & . \\
\hline Student 29 & Weak & 5 & 5 & 8 & 8 & 6 & 31 & $\begin{array}{l}\text { Good Conceptual } \\
\text { Knowledge }\end{array}$ \\
\hline Student 30 & Weak & 2 & 3 & 5 & 3 & 4 & 17 & $\begin{array}{l}\text { Scope for Conceptual } \\
\text { Knowledge Improvement }\end{array}$ \\
\hline
\end{tabular}

On first day, during first session students were exposed to the fundamentals of Arduino. By this session students had in-depth knowledge of Arduino and hence were able to know basics of Arduino and its application in various domain in present technological era. Only theoretical assignment was given to students for this session and the assessment was completed by faculty members. The second and third sessions comprised of various hands-on using Arduino. The hands-on laboratory sessions included working with various peripherals such as LED, switches, serial port, Light Dependent Resistors (LDR), and intensity variation using Pulse Width Modulation (PWM), relay control, temperature sensors, actuators, display devices and many more. The theoretical and hands-on laboratory assignments were given on each of these sessions and assessment was done by the faculty members.

On second day, fourth and fifth sessions also had hands-on laboratory practice which included interfacing of high end devices like wireless communication including Bluetooth, and understanding MATLAB support to Arduino. In the sixth session of workshop, open ended design problems were given to the students. In fixed duration written exam, it is not possible to assign problem statements which will trigger creativity of students. The problem statements for last session were drafted to achieve highest level of Bloom's taxonomy in the solutions. The theoretical and hands-on knowledge gain during entire workshop was required to devise solution for this problem statement. Students proposed solution for the given problem on paper. The solution presented by students were critically evaluated by faculty \& feedback was given to them for necessary correction. This process was iterative till the time technically sound solution was ready. Once the faculty approved the design made by students they were allowed to implement it using Arduino board. The problems encountered during implementation of the design were rectified by the students under the guidance of the faculty.

\section{Result and Analysis}

Every session was followed by assignment to analyse the knowledge gained during the session. There were total 5 theoretical assignments and 4 hands-on laboratory assignments given to the students. As last session was planned to allow students to apply knowledge gained during entire workshop, open ended design problems were given. Students' performance of this session was evaluated separately for design and implementation of the solution to the given problem.

Each theoretical assignment was for 10 marks. As there were 5 assignments, students scoring $60 \%$ and above marks out of 50 marks, were informed as having "Good Conceptual Knowledge" while others were given the feedback as "Scope for Conceptual Knowledge Improvement." Table 3 shows few entries from result of theoretical assignment evaluation. Similarly, each hands-on laboratory assignment was for 10 marks. As there were 4 assignments, students scoring $60 \%$ and above marks out of 40 marks, were informed as having "Good Hands-on Laboratory Skills" while others were given the feedback as "Scope for Hands-on Laboratory Skills Improvement." Table 4 shows few entries from result of hands-on laboratory assignment evaluation. 
The design of the solution was evaluated for 25 marks. The students who have scored $60 \%$ and above, were marked as having "Good Problem Solving Skills" while others were given the feedback as "Scope for Problem Solving Skills Improvement". Table 5 shows few entries from result of design assignment evaluation.

Table 5. Performance of Students in Design

\begin{tabular}{|c|c|c|l|}
\hline Name & $\begin{array}{c}\text { Identificat } \\
\text { ion }\end{array}$ & $\begin{array}{c}\text { Session 6: } \\
\text { Design }\end{array}$ & \multicolumn{1}{|c|}{ Remark } \\
\hline Student 1 & Bright & 10 & $\begin{array}{l}\text { Scope for } \\
\text { Problem Solving } \\
\text { Skills } \\
\text { Improvement }\end{array}$ \\
\hline Student 2 & Bright & 15 & $\begin{array}{l}\text { Good Problem } \\
\text { Solving Skills }\end{array}$ \\
\hline Student 3 & Weak & 16 & $\begin{array}{l}\text { Good Problem } \\
\text { Solving Skills }\end{array}$ \\
\hline$\cdot$ & $\cdot$ & $\cdot$ & $\cdot$ \\
\hline$\cdot$ & $\cdot$ & $\cdot$ & \multicolumn{1}{|c|}{} \\
\hline Student 29 & Weak & 17 & $\begin{array}{l}\text { Good Problem } \\
\text { Solving Skills }\end{array}$ \\
\hline Student 30 & Weak & 18 & $\begin{array}{l}\text { Good Problem } \\
\text { Solving Skills }\end{array}$ \\
\hline
\end{tabular}

The implementation of the design was evaluated for 25 marks. The students who have scored $60 \%$ and above marks, were reported as having "Good Execution Skills" while others were given the feedback as "Scope for Execution Skills Improvement". Table 6 shows few entries from result of implementation assignment evaluation.

Table 6. Performance of Students in Implementation Assignment

\begin{tabular}{|c|c|c|l|}
\hline Name & $\begin{array}{c}\text { Identifica } \\
\text { tion }\end{array}$ & $\begin{array}{c}\text { Session 6: } \\
\text { Implemen } \\
\text { tation }\end{array}$ & \multicolumn{1}{|c|}{ Remark } \\
\hline Student 1 & Bright & 10 & $\begin{array}{l}\text { Scope for } \\
\text { Execution Skills } \\
\text { Improvement }\end{array}$ \\
\hline Student 2 & Bright & 16 & $\begin{array}{l}\text { Good Execution } \\
\text { Skills }\end{array}$ \\
\hline Student 3 & Weak & 17 & $\begin{array}{l}\text { Good Execution } \\
\text { Skills }\end{array}$ \\
\hline$\cdot$ & $\cdot$ & $\cdot$ & \\
\hline$\cdot$ & $\cdot$ & $\cdot$ & \\
\hline
\end{tabular}

\begin{tabular}{|l|c|c|l|}
\hline Student 29 & Weak & 12 & $\begin{array}{l}\text { Scope for } \\
\text { Execution Skills } \\
\text { Improvement }\end{array}$ \\
\hline Student 30 & Weak & 18 & $\begin{array}{l}\text { Good Execution } \\
\text { Skills }\end{array}$ \\
\hline
\end{tabular}

The sample of design assignment questions and rubrics used for assessment of theoretical assignment is provided in appendix.

The performance of bright and weak students is analysed in all four type of assignments given during the workshop.

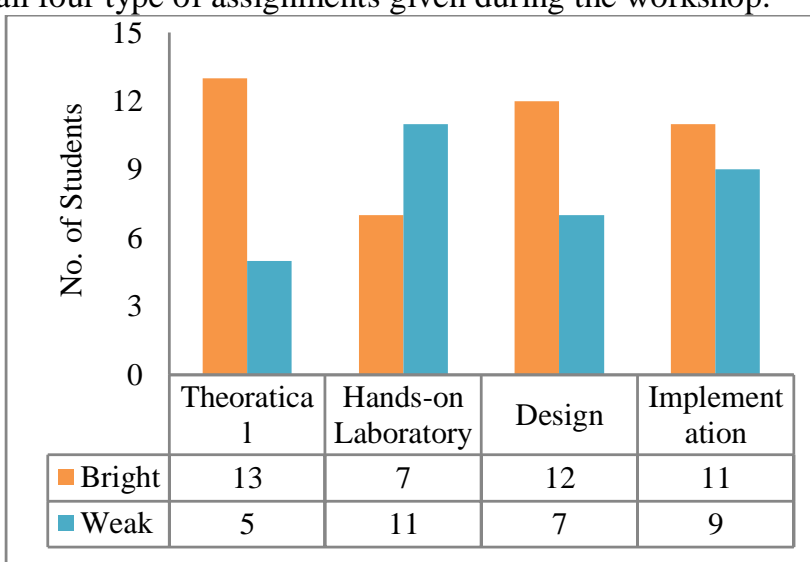

Fig. 1: Comparison of "Good" Performing Bright and Weak Students

The Figure 1 shows the comparison of "Good" performing bright and weak students on the basis of theoretical, handson laboratory, design and implementation assignments. It was found that out of 15 weak students, 11 students received a "Good Hands-on Laboratory Skills" remark for hands-on laboratory assignment, however only 5 students received "Good Conceptual Knowledge" remark for theoretical assignment. On the other hand, out of 15 bright students 13 students received a remark of "Good Conceptual Knowledge" for theoretical assignment however only 7 students received a remark of "Good Hands-on Laboratory Skills" for handson laboratory assignment.

It was found that out of 15 weak students, 7 students received "Good Problem Solving Skills" remark for design assignment. The faculty has given inputs for corrections to the solution of design assignment of remaining 8 students. This way, all weak students were having correct solution for design assignment. However only 9 students received "Good Execution Skills" remark for implementation assignment. In case of 15 bright students, 12 students received a remark of

Table 4. Performance of Students in Hands-on Laboratory Assignment

\begin{tabular}{|c|c|c|c|c|c|c|c|}
\hline Name & Identification & Session 2 & Session 3 & Session 4 & Session 5 & Total & Remark \\
\hline Student 1 & Bright & 5 & 5 & 6 & 5 & 21 & $\begin{array}{l}\text { Scope for Hands-on Laboratory } \\
\text { Skills Improvement }\end{array}$ \\
\hline Student 2 & Bright & 8 & 8 & 8 & 8 & 32 & $\begin{array}{l}\text { Good Hands-on Laboratory } \\
\text { Skills }\end{array}$ \\
\hline Student 3 & Weak & 6 & 6 & 4 & 5 & 21 & $\begin{array}{l}\text { Scope for Hands-on Laboratory } \\
\text { Skills Improvement }\end{array}$ \\
\hline . & . & . & . & . & . & . & . \\
\hline . & . & . & . & . & . & . & . \\
\hline Student 29 & Weak & 5 & 5 & 854 & 8 & 26 & $\begin{array}{l}\text { Good Hands-on Laboratory } \\
\text { Skills }\end{array}$ \\
\hline Student 30 & Weak & 2 & 3 & 5 & 3 & 13 & $\begin{array}{l}\text { Scope for Hands-on Laboratory } \\
\text { Skills Improvement }\end{array}$ \\
\hline
\end{tabular}


"Good Problem Solving Skills" for design assignment and faculty has corrected the solution of other 3 students. For implementation assignment, 11 bright students received a remark of "Good Execution Skills".

It has been observed that weak students are lagging behind bright students except for hands-on laboratory assignment. It has been also observed that, with the help of faculty once these students got their design corrected, most of them have implemented it successfully. The difference between performance of weak and bright students' implementation is negligible. Hence it can be stated that, weak students are more inclined towards hands-on and implementation and lacks interest in theoretical aspect. As expected bright students performed well in all sort of assignments. But took interest in learning the theoretical part rather than its implementation.

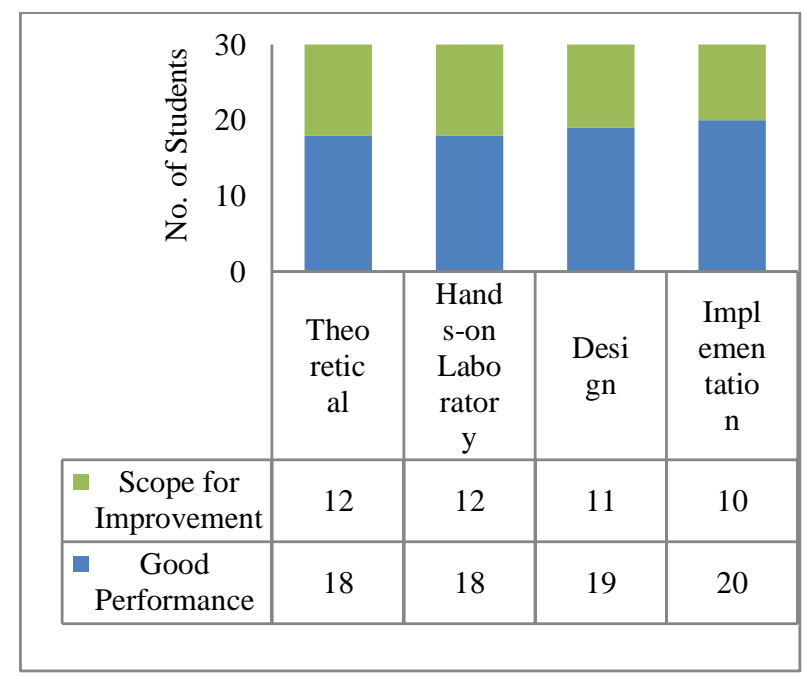

Fig. 2: Overall Students' Performance

Figure 2 shows the performance of all students on the basis of theoretical, hands-on laboratory, design and implementation assignment. Overall, 60\% and above students have completed all the assignments with "Good" remark. Rest of the students, received necessary feedback for improvement from the faculty members.

\section{Conclusions}

From this skills development activity, it can be concluded that, performance of the students is directly proportional to their interest. Brighter students are performing well on theoretical \& design frontier while weaker students are performing better on hands-on \& implementation of design. As a teacher, we are interested that all students should take similar interest in every aspect. To achieve this, weak students can be motivated to pursue theoretical aspects and bright students can be involved in hands-on activities. A group consisting of equal number of bright and weak students will help them to improve their technical skills, moreover it will inculcate teamwork quality amongst them. This way, the gap between weak \& bright students can be bridged and weak students can be motivated to improve their confidence level. It also evident that weak students may lacks theoretical knowledge but they possess good hands-on skills. Hence, teacher must pay extra attention to them to enhance their capabilities instead of neglecting them.

Through this activity, students have understood the importance of hands-on laboratory skills \& execution skills. In future, to engage all students properly, they can be classified as weak, average and bright and relevant activities can be planned by the teacher.

\section{Acknowledgements}

The authors wishes to appreciate the efforts taken by staff members of the department of electronics and telecommunication engineering of the institute for their cooperation during conduction of this hands-on workshop activity.

\section{References}

[1] Julie Arnold, Robert Kackley, Stephen Fortune. (2003) Hands-on Learning for Freshman Engineering Students Issues in Science and Technology Librarianship, doi: 10.5062/F4XD0ZNQ

[2]Daniela Pusca, Randy J. Bowers \& Derek O. Northwood, (2017) Hands-on experiences in engineering classes: The need, the implementation and the results, World Transactions on Engineering and Technology Education, Vol.15, No.1

[3] Nina Holstermann, Dietmar Grube, (2010) Hands-on Activities and Their Influence on Students' Interest, Article in Research in Science Education. doi: 10.1007/s11165-0099142-0.

[4] Dr. U M Daivagna, S B Yapalaparvi, D N Inaamadar, N K Honnagoudar, Towards improving the Performance of the Weak Students through Identification and effective Implementation of Tasks by the Quality Circle, Journal of Engineering Education Transformations, Special Issue, eISSN 2394-1707.

[5] Wan Maziah Wan Ab Razak, Sharifah Alia Syed Baharom, Zalinawati Abdullah, Haslenna Hamdan, Nurul Ulfa Abd Aziz, Ahmad Ismail Mohd Anuar,(2019) Academic Performance of University Students: A Case in a Higher Learning Institution, KnE Social Sciences, KnE Social Sciences/The 2nd International Conference on Islamic Economics, Business, and Philanthropy (2nd ICIEBP), pp 1294-1304, doi: 10.18502/kss.v3i13.4285.

[6] National Project Implementation Unit, A Unit of MHRD, Govt of India for Implementation of World bank Assisted Projects in Technical Education, Technical Education Quality Improvement Programme (TEQIP) PHASE-II, Improving the Academic Performance of Weak Students through an Equity Action Plan, 2015. http://www.npiu.nic.in/teqip2document.html

[7] Dr. M T Taher, Dr. Usman Ghani, (2017) A Comparative Study for Determining the Impact of Simulation-based, Handson and Feedback Mechanisms on Students' Learning in Engineering Technology and Computer Networking Programs, American Society for Engineering Education, paper ID \#17788 
[8] Durik AM, Harackiewicz JM., (2007) Different strokes for different folks: How individual interest moderates the effects of situational factors on task interest. Journal of Educational Psychology. 99:597-610. doi: 10.1037/00220663.99.3.597

\section{Appendix}

Sample Questions for Design Assignment

Design any of the following system using Arduino board.

1. Home security system with at least 3 sensors.

2. Robot system that can move in forward, reverse direction.

3. Function generator

4. Frequency counter

5. Traffic control system

Prepare circuit diagram, interfacing diagram, algorithm and code.

Sample Rubrics for Assessment of Theoretical Assignment

\begin{tabular}{|c|c|c|c|}
\hline Criteria & Excellent & Good & Beginner \\
\hline Contents & $\begin{array}{l}\text { All points } \\
\text { covered } \\
\end{array}$ & $\begin{array}{l}\text { Partially } \\
\text { coverage } \\
(\mathbf{3 - 2})\end{array}$ & $\begin{array}{l}\text { Not up to } \\
\text { the mark }\end{array}$ \\
\hline $\begin{array}{l}\text { Writing } \\
\text { Skills } \\
\end{array}$ & $\begin{array}{l}\text { Well } \\
\text { organized } \\
\end{array}$ & $\begin{array}{l}\text { Better } \\
\text { organized } \\
\end{array}$ & $\begin{array}{l}\text { Poorly } \\
\text { organized } \\
\qquad(\mathbf{1 - 0})\end{array}$ \\
\hline $\begin{array}{l}\text { Supporting } \\
\text { material } \\
\text { (2) }\end{array}$ & $\begin{array}{l}\text { Relevant } \\
\text { (2) }\end{array}$ & $\begin{array}{l}\text { Partially } \\
\text { relevant } \\
\end{array}$ & Irrelevant \\
\hline
\end{tabular}

